Esta publicación científica en formato digital es continuidad de la revista impresa ISSN-Versión Impresa 0798-1406 / ISSN-Versión on line 2542-3185Depósito legal pp

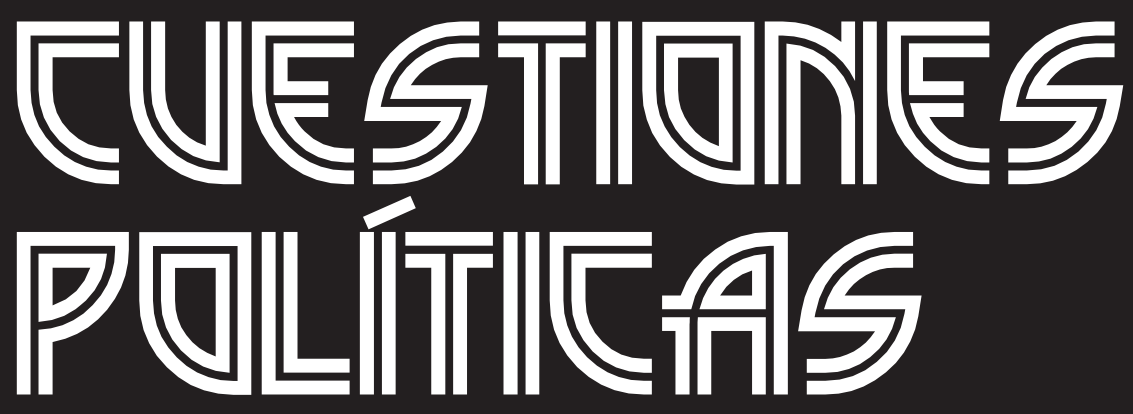

Instituto de Estudios Políticos y Derecho Público "Dr. Humberto J. La Roche" de la Facultad de Ciencias Jurídicas y Políticas de la Universidad del Zulia Maracaibo, Venezuela
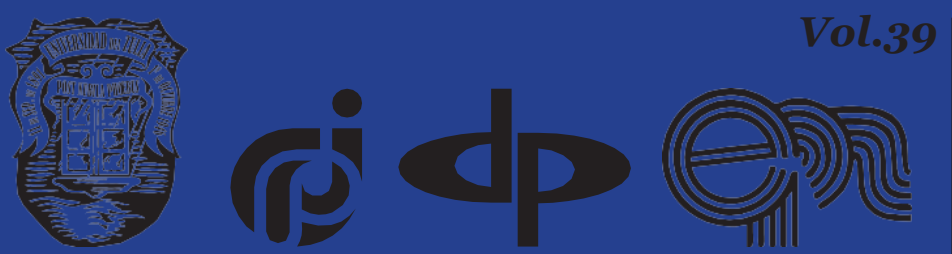


\title{
The Financial Implications of the Coronavirus COVID-19 Pandemic: A Review
}

\author{
DOI: https://doi.org/10.46398/cuestpol.3968.20
}

\author{
Ilmir Nusratullin * \\ Nikolay Mrochkouskiy ${ }^{* *}$ \\ Raul Yarullin *** \\ Natalia Zamyatina \\ Oksana Solntseva $* * * * *$
}

\section{Abstract}

The COVID-19 pandemic in 2020 was a real shock to the entire global community. It hit both the health systems of the infected countries and the economies. Border closures, quarantines for citizens and disruption of production caused economic shock to many organizations. First, the tourism and transport industry suffered, followed by agriculture and mining, and then all other industries. However, the economic crisis also caused some problems in the financial sector: increased risks of non-compliance with loans, cash outs of bank deposits, increased pressure on the insurance market, panic in commodity and securities markets. The purpose of this study is to examine the impact of COVID-19 on the financial system of developed countries. As part of this study, a review of scientific research in the field of pandemics and finances was conducted, how the spread of infection affected the economy, banking, financial markets, and government regulation in the financial sector as a whole.

Keywords: COVID-19; pandemic; finance and pandemic; financial impact analysis; political economy.

* Bashkir State University, Russia. ORCID ID: https://orcid.org/oooo-ooo1-7810-2945. Email: nusratullin.iv@gmail.com

** Plekhanov Russian University of Economics, Russia. ORCID ID: https://orcid.org/oooo-ooo1-84533944. Email:mnikos@ya.ru

**** Financial University under the Government of the Russian Federation, Moscow, Russia. ORCID ID: https://orcid.org/oooo-ooo1-6834-3032. Email: jrr61@mail.ru

**** State University of Management, Moscow, Russia. ORCID ID: https://orcid.org/oooo-ooo1-81846304. Email: zamiatina.guu@gmail.com

***** State University of Management, Moscow, Russia. ORCID ID: https://orcid.org/oooo-ooo1-68108868. Email: osolntse@mail.ru 


\section{Las implicaciones financieras de la pandemia de coronavirus COVID-19: Una revisión}

\section{Resumen}

La pandemia de COVID-19 en 2020 fue un verdadero shock para toda la comunidad mundial. Golpeó tanto a los sistemas de salud de los países infectados como a las economías. El cierre de fronteras, las cuarentenas para los ciudadanos y la interrupción de la producción provocaron un shock económico para muchas organizaciones. En primer lugar, la industria del turismo y el transporte sufrió, seguida de la agricultura y la minería, y luego de todas las demás industrias. Sin embargo, la crisis de la economía también provocó ciertos problemas en el sector financiero: aumento de los riesgos de incumplimiento de los préstamos, salidas de efectivo de los depósitos bancarios, aumento de la presión en el mercado de seguros, pánico en los mercados de materias primas y valores. El propósito de este estudio es examinar el impacto de COVID-19 en el sistema financiero de los países desarrollados. Como parte de este estudio, se realizó una revisión de la investigación científica en el campo de la pandemia y las finanzas, cómo la propagación de la infección afectó a la economía, el sector bancario, los mercados financieros y la regulación gubernamental en el sector financiero en su conjunto.

Palabras clave: COVID-19; pandemia; finanzas y pandemia; análisis de impacto financiero; economía política.

\section{Introduction}

The COVID-19 pandemic in 2020 has led to serious social, economic, and political crises. Since its appearance, the COVID-19 virus has become not just a large health problem, but a cause of change in people's ways of life. In December 2019, the virus was recorded in Wuhan (Hubei Province, China), and in a few months, it had spread to all continents (Huang et al, 2020). As of September 30, 2020, about 33.6 million infections, 1 million deaths were recorded worldwide (Google news, 2020).

The relevance of this study is that the COVID-19 pandemic is not the first serious problem of a similar level that humanity has faced in recent decades, for example, an outbreak of H1N1 in 2009, polio in 2014, Ebola in West Africa in 2014, Zika in 2016 and Ebola in the Democratic Republic of the Congo in 2019 (Allocati et al, 2016). Later, on January 30, 2020, the WHO announced the sixth public health emergency of the 21st century - COVID-19. These worldwide outbreaks have caused a large number of deaths, diseases and cost billions of dollars (Fan et al, 2019). This suggests that despite the initial first signals of a possible global pandemic, few steps have been taken to prepare for it. 
Back in 2018, Bloom, Cadarette and Sevilla (2018) warned of the need to prepare for possible future pandemics and epidemics in their study. In their view, pandemics and epidemics will lead to increased costs for the healthcare system by increasing the costs associated with treating the infected persons and fighting outbreaks. In addition, a pandemic, according to Bloom, Cadarette and Sevilla (2018), will contribute to social distancing, disruption of economic ties, a decrease in production volumes, losses in tourism, and a decrease in investment activity, all of which ultimately happened in 2020 because of COVID-19.

Lewis (2001), wrote about the economy during an epidemic; in his opinion, a pandemic can lead to high healthcare costs, a decrease in national economic potential and political instability. Bloom and Canning (2004) argued that epidemics can have significant economic consequences - both in the short and long term, their management and control will require significant investments in national and international health systems. The need for preparing for global pandemics is explained by the fact that they may incur significant human and economic costs. This study makes a contradictory conclusion that, on the one hand, the growth of well-being in countries leads to higher healthcare costs and thereby to preparing for possible epidemics, and on the other hand, globalization leads to increased risks of the spread of a future epidemic around the world, rather than only in any localized territories.

In the same way, Arbeláez-Campillo and Villasmil (2020), also argue that the ravages caused by the COVID-19 pandemic in the first half of 2020 , erode in such a way the foundations of the prevailing world order, structured since the aftermath of the Second War world, which already articulates the conditions of possibility for the emergence of a new or renewed international order with uncertain characteristics.

Tam et al. (2016), wrote on migration issues and their impact on the economy as a result of future pandemics. Yach, Stuckler, and Brownell (2006), conducted a study on the impact of the global obesity and diabetes epidemic on a state's economy.

The current COVID-19 pandemic, despite the fact that it is only now in full swing, already has a number of negative consequences for health, society and the economy:

1. In healthcare. The range of clinical cases of COVID-19 infection ranges from mild or nonspecific signs and symptoms of acute respiratory failure, such as fever, cough, fatigue, shortness of breath, to severe pneumonia with respiratory failure and septic shock, which are very similar to other coronavirus diseases. More severe forms of COVID-19 affect older people. COVID-19 is becoming one of the main causes of hospitalization and mortality, in particular among 
Ilmir Nusratullin, Nikolay Mrochkovskiy, Raul Yarullin, Natalia Zamyatina y Oksana Solntseva The Financial Implications of the Coronavirus COVID-19 Pandemic: A Review

middle-aged and elderly people in affected countries (Backer et al., 2020).

2. In society. Because of the outbreak of COVID-19, in almost every infected country restrictions have been placed on population movements from a few weeks to several months. Local and central administrations around the world have banned the free movement of their citizens outside of their homes to avoid transmission of the virus. Various religious, cultural, social, scientific, sporting and political mass events were canceled. Also, due to the fact that all family members are constantly together, there is a surge in domestic violence (Campbell, 2020).

3. In the economy. The COVID-19 pandemic hit the infected countries economically. In transport; passenger international air, rail, and auto traffic almost completely ceased due to quarantine measures. Following the cessation of population movement, tourism-related sectors (tourism organizations, HoReCa and entertainment) were affected. Cargo freight suffered less. In addition, educational, commercial, sports, and spiritual institutions were closed in countries prone to infection in order to prevent the spread of the virus through crowds of people. In many countries, restrictions on mobility have been introduced, and as a result, the public service sector has practically stopped (Chakrabortya and Maityb, 2020)

As part of this study, the author will conduct a review of research in the field of the pandemic and finance, how infections generally affect the economy, the banking sector, the financial markets, and the government regulation of the financial sector in the pandemic. The topic of the impact of epidemics and pandemics on the financial system of the country and the whole world has previously been seldom considered, so there is not much research in this area. This paper aims to fill this knowledge gap and formulate approximate directions for further research.

\section{Materials and Methods}

The research base was taken from scientific studies conducted from 2000 to 2020, which relate to the impact of pandemics on the economy as a whole, the banking sector, the financial markets, the government regulation of the financial sector during the pandemic. In addition, the author used the World Bank's data (https://datacatalog.worldbank.org/) regarding the measures taken by different states in the field of finance in order to mitigate the consequences of the COVID-19 pandemic. 


\section{Results}

\subsection{COVID-19 and the Economic Crisis}

An outbreak of a new coronavirus infection COVID-19 was reported in Wuhan (Hubei Province, China) in December 2019. After hitting China in February-March, the virus began to spread actively in South Korea, Iran, Italy, and then in Europe, the USA, and Russia (Sohrabi et al, 2020; Yang et al, 2020). As of April 24, 2020, about 2.8 million infections, 0.8 million recoveries, 0.2 million deaths were recorded worldwide as of September 30, 2020, about 33.6 million infections, 1 million deaths were recorded worldwide (Google news, 2020).

Deaths during epidemics and pandemics have always caused some irreparable damage to society, but COVID-19 is different as it has immobilized the entire global economy. In order to limit the further transmission of the disease in society, many of the affected countries decided to completely isolate themselves - closing borders (AL JAZEERA, 2020) and society self-isolation regimes (for example, (GOV.UK, 2020)). Most international flights were canceled, many local flights and rail transportation were also canceled, and bus and road connections were limited. Of course, all this applies to passenger transportation, cargo freight remained practically unlimited. In almost all countries affected by COVID-19, educational, scientific, sports and spiritual institutions were closed. The sectors of tourism and entertainment were hit hard. In countries where the epidemic is particularly acute, production facilities are temporarily closed. All this leads to an increase in unemployment and a drop in the income level of the population, which can subsequently lead to a protracted economic crisis and recession (Buck et al, 2020).

In (Nicola et al, 2020), analyzing the news reports, the authors identified the following economic consequences of the COVID-19 pandemic:

- As a result of a global drop in demand from hotels and restaurants, agricultural prices fell by $20 \%$.

- Disturbance of the commodity exchanges operations due to panic in commodities' markets.

- A deficit in the medical and pharmaceutical markets for medical goods and personal protective equipment due to a sharp jump in demand.

- High volatility in the oil market due to lower global oil demand and problems within OPEC.

- High concern from the business community on the situation around the pandemic, the expectation of a decrease in turnover over the next two quarters. 
- A decrease in production of the chemical industry worldwide by $1.2 \%$.

Thus, a slowdown in economic development is observed, and in countries particularly affected by the pandemic, economic crises and recession are possible.

\subsection{COVID-19 and the Banking System}

In the modern world, pandemics and epidemics do not directly affect the banking sector, the effect being more indirect:

1. The development of an epidemic leads to an increase in population spending on healthcare, which leads to a decrease in the size of the deposits with the banks or can lead to their closures (Leoni, 2013). This conclusion was made by Leoni by examining the data on the spread of HIV in developing countries. The population of these countries is forced to pay for individual treatment at the expense of cash on deposits. Since HIV treatment is long and expensive, often people spend almost all of their savings.

2. If people do not have adequate savings for treatment during a pandemic, they apply for loans from microfinance organizations and banking institutions, however, repayment of such loans is associated with great risks, as the situation in the labor market continues to worsen and people simply do not have money to repay loans (Lagoarde-Segot and Leoni, 2013).

3. In a banking crisis caused by external unpredictable factors: natural disasters, global crises, and possibly pandemics (this factor is not directly considered in the study), banks pursue more conservative policies in order to restore profitability (Bongini et $a l$, 2019). However, such policies during a pandemic may, on the contrary, aggravate the economic crisis, as businesses simply cannot find money to recover, and then through a contagion effect, unemployment increases, individual deposits with banks decrease, risks associated with lending increase, and bank profitability takes an even further drop.

Thus, a pandemic affects the banking sector through the emerging economic crisis. The termination of business cooperation due to the closure of borders, the shutdown of production facilities and services due to quarantine measures, and an increase in healthcare and medical treatment costs lead to a drop in profit for the business community and in the income of the population. In addition, both the business and the public begin to 
spend their own savings. All of this leads to increased risks in the banking sector and an outflow of capital from banking institutions.

\subsection{COVID-19 and the Insurance System}

The pandemic has placed a heavy burden on the insurance system, especially on both the public and private health insurance systems. Local epidemics and pandemics are not capable of causing catastrophic failures in the insurance system, as there is global reinsurance (Tamura and Sawada, 2009). However, studies regarding the impact of the global pandemic on the global insurance system have not yet been conducted; this may be interesting for further studies.

Specifically, for the global insurance system, COVID-19 has become a kind of stability test, one will be able to find out later how successful it was.

\subsection{COVID-19 and the Stock Market}

Stock market quotes are affected by both current speculative factors and fundamental factors, including those that are difficult to predict. The impact on the stock markets from political events was studied by Bash and Alsaifi (2019) and Shanaev and Ghimire (2019), from natural disasters, for example, by Kowalewski and Śpiewanowski (2020), from environmental disasters, for example, by Alsaifi et al. (2020) and Guo et al. (2020).

There are also some studies on the impact of pandemics on stock markets, for example:

1. Acute Respiratory Syndrome (SARS)outbreak (Chen et al, 2007).

2. Ebola Virus Disease (EVD) outbreak (Ichev and Marinč, 2018).

The results by Al-Awadhia et al., (2020) who studied the effects of COVID-19 on the stock market, are interesting. The results of the study indicate a significant negative effect from the pandemic on all companies included in The Hang Seng Index and Shanghai Stock Exchange Composite Index. It should be noted that some sectors of the economy showed positive results during the outbreak of COVID-19, namely: IT and pharmaceutical companies.

In general, studies of the impact of pandemics on stock markets are inadequate; there are studies of the effects of natural disasters, technological disasters, terrorist attacks, and armed conflicts. However, all these studies are local in nature, and COVID-19 is different, being global in nature. Therefore, its impact on the stock market can be better compared with global economic crises. 
Ilmir Nusratullin, Nikolay Mrochkovskiy, Raul Yarullin, Natalia Zamyatina y Oksana Solntseva The Financial Implications of the Coronavirus COVID-19 Pandemic: A Review

\subsection{COVID-19 and the Stock Market.}

The COVID-19 pandemic is global. However, as many countries have chosen to isolate and have closed their borders, these countries are now fighting against the virus in the financial markets on their own. Next, consider the responses of China (Table 1), the USA (Table 2) and Russia (Table 3) in the financial market to the COVID-19 pandemic.

\begin{tabular}{|c|c|}
\hline Financial Institutions & Liquidity/funding \\
\hline $\begin{array}{l}\text { Require banks and insurance companies to ensure the } \\
\text { safety, smoothness and efficiency of financial service; } \\
\text { Provide fast path for affected operations and businesses } \\
\text { The National Development and Reform Commission } \\
\text { allowed high-quality small and medium-sized } \\
\text { enterprises (SMEs) to issue corporate bonds. This } \\
\text { measure enabled businesses to redeem loans and } \\
\text { replenish operating assets. } \\
\text { Policy banks of China issued } 26.5 \text { billion yuan of } \\
\text { special bonds at advantageous interest rates to support } \\
\text { activities related to epidemic control. They will also } \\
\text { provide specialized credit funds of } 350 \text { billion yuan to } \\
\text { small and medium private enterprises. } \\
\text { Loan forbearance encouraged credit institutions } \\
\text { to increase lending to companies most affected by the } \\
\text { pandemic and ensure flexible repayment conditions } \\
\text { until June } 30 \text { for micro, small and medium-sized } \\
\text { enterprises and households. } \\
\text { The State Council announced a series of measures } \\
\text { to support medium, small and micro firms (MSMEs) } \\
\text { via inclusive financing measures - i) re-discount and } \\
\text { relending loan quota will be increased by RMB } 1 \text { trn, } \\
\text { targeting mainly medium-sized and small banks ii) } \\
\text { another targeted RRR cut for these banks has been pre- } \\
\text { announced iii) financial institutions are allowed to issue } \\
\text { RMB } 300 \text { bn financial bonds to support small and micro } \\
\text { firms' loan extension iv) the government will window- } \\
\text { guide corporate bond financing this year by increasing } \\
\text { RMB } 1 \text { trn corporate bonds from last year's net level } \\
\text { to expand financing channels for private firms and } \\
\text { MSMEs and low their financing costs v) the regulators } \\
\text { will encourage MSMEs receivables financing bv RMB }\end{array}$ & $\begin{array}{l}\text { The medium-term lending } \\
\text { rate was reduced by 10 } \\
\text { basis points and amounted } \\
\text { to 4.050\%; 200 billion } \\
\text { yuan (0.2 percent of gross } \\
\text { domestic product) were } \\
\text { injected into the economy } \\
\text { through the medium-term } \\
\text { lending facility. } \\
\text { Since February 3, RMB } 2.8 \\
\text { trillion was injected through } \\
\text { open market operation, } \\
\text { although most of it was later } \\
\text { withdrawn. } \\
\text { The re-lending and re- } \\
\text { discount facilities were used } \\
\text { to support SMEs (RMB } \\
500 \text { billion); the re-lending } \\
\text { interest rate was reduced and } \\
\text { amounted to } 2.5 \text { percent. } \\
\text { A re-lending program } \\
\text { totalling RMB } 300 \text { billion } \\
\text { was specially designed for } \\
\text { enterprises affected by the } \\
\text { pandemic, at a rate of } 1.3 \\
\text { percent, subsidized by the } \\
\text { Ministry of Finance. } \\
\text { The 7-day reverse repo } \\
\text { rate was reduced by } 20 \text { basis } \\
\text { points, to } 2.2 \% \text {. }\end{array}$ \\
\hline
\end{tabular}


On February 5, 2020, the People's Bank of China (PBC) published Notices on anti-money laundering/ combating the financing of terrorism (AML/CFT) requirements to respond to the COVID-19 outbreak, intended for its branches. PBC branches were to carry out more pragmatic supervision adjusted to local specifics and ensure guidance to local entities facing problems in meeting regulatory requirements. The $\mathrm{PBC}$ also encouraged all regulated entities to prepare contingency programs for complying with the AML/CFT requirements by taking advantage of the full range of tools provided by the Responsible Business Alliance. To support charity and medicine, due diligence measures were simplified for low-risk products and services.
The required

reserve ratio (RRR) was reduced by 0.5 percent for rural credit unions, rural, commercial and cooperative banks, and also for city commercial banks operating exclusively in provincial-level administrative regions. It was one of the two planned reductions of 0.5 percent each.

The medium-term lending rate was cut to $2.95 \%$.

The excess deposit reserve rate was cut from $0.72 \%$ to $0.35 \%$.

Table 1. China's Response to the Development of the COVID-19 Epidemic in 2019-2020

Source: (The world bank group, 2020).

China's reaction to the development of the COVID-19 epidemic can be divided into 2 parts: the first is support for financial institutions and regulation of their activities, the second is support for liquidity and pumping money into the economy.

\begin{tabular}{|c|c|}
\hline Financial institutions & Liquidity/funding \\
\hline $\begin{array}{l}\text { The composition of capital was } \\
\text { changed to comply with Pillar } 2 \\
\text { requirements: credit institutions } \\
\text { received the right to partially use capital } \\
\text { tools not qualified as CET1 capital (a } \\
\text { measure earlier scheduled to enter into } \\
\text { force in January 2021). It was expected } \\
\text { that banks would use the positive } \\
\text { impact of these measures to support the } \\
\text { economy, not to increase dividends or } \\
\text { variable compensation. } \\
\text { The Federal Reserve Board } \\
\text { introduced temporary changes to its } \\
\text { leverage ratio requirements to reduce } \\
\text { tension in the treasury market caused } \\
\text { by the pandemic and improve banks' } \\
\text { abilities to provide loans to individuals } \\
\text { and businesses. }\end{array}$ & $\begin{array}{l}\text { The interest rate target range was } \\
\text { reduced from 1.00-1.25\% to o.oo- } \\
\text { 0.25\%. } \\
\text { The primary credit rate of the } \\
\text { discount window was reduced from } \\
\text { 1.75\% to } 0.25 \% \text {. } \\
\text { Interim USD liquidity arrangements } \\
\text { (swap lines) with nine countries } \\
\text { (Australia, Brazil, Denmark, Norway, } \\
\text { Mexico, Korea, New Zealand, Singapore, } \\
\text { and Sweden) were announced. } \\
\text { Within the framework of the } \\
\text { quantitative easing policy, the Federal } \\
\text { Reserve announced purchases of US } \\
\text { treasuries (USD 50o billion) and agency } \\
\text { mortgage-backed securities (USD } 200 \\
\text { billion). }\end{array}$ \\
\hline
\end{tabular}


Since the second quarter of 2020 and until the end of December, a bank having a leverage ratio of $8 \%$ or more and complying with some additional criteria can use the community bank leverage ratio rules. For community banks, these rules will be in effect until January 1, 2022, before the requirement for the community bank leverage ratio requirement is again set at more than $9 \%$.

A revised statement was issued concerning the interaction between the interagency statement of March 22, 2020 and the temporary aid provided by Section 4013 of the Coronavirus Aid, Relief, and Economic Security Act signed on March 27, 2020.

The Securities and Exchange Commission announced that financial organizations taking advantage of the Coronavirus Aid, Relief, and Economic Security Act provision allowing the deferral of implementation of two Generally Accepted Accounting Principles (GAAP) would not violate GAAP.

Temporary exemptive relief was ensured for business development companies that obtained the possibility to additionally invest in small and medium-sized businesses.

Capital rules were changed to compensate for the regulatory capital impact of participating in the Federal Reserve's Paycheck Protection Program (PPP) since no market or credit risk is associated with PPP loans.

The Federal Reserve Board, Federal Deposit Insurance Corporation, and Office of the Comptroller of the Currency announced a temporary regulation to encourage lending through the PPP, specifying that a zero percent risk weight should be applied to loans covered by the PPP for capital purposes.
The Federal Reserve cut the discount rate by 150 basis points with a simultaneous increase in the lending term to 90 days.

The required reserve ratio was reduced to zero.

The programs launched during the Global Financial Crisis were reintroduced, in particular, the Commercial Paper Funding Facility, as well as the Primary Dealer Credit Facility, allowing for more aggressive lending over a longer horizon at the discount rate.

The Federal Reserve also introduced large-scale repo operation with increased terms - one-month and three-month tranches. This could result in additional liquidity of USD 5 trillion, although the actual increase has been much less so far.

An amendment to the Federal Reserve Act was proposed, according to which the Fed would receive the right to buy municipal bonds in certain circumstances.

A new repo facility for foreign and international monetary authorities (FIMA) was introduced. This facility made it possible for monetary authorities having accounts at the Federal Reserve Bank of New York to conclude repurchase agreements with the Federal Reserve, temporarily exchange their U.S. Treasury securities for U.S. dollars and then ensure access to these funds for institutions in their countries. This facility has been available since April 6, 2020 and will be in effect for at least six months.

The Paycheck Protection Program Liquidity Facility was created to extend credit to financial organizations originating PPP loans. 
The Federal Reserve announced readiness to provide four-year loans through banks to enterprises with up to ten thousand employees and to extend loans directly to states, counties, and cities to help them deal with the pandemic. This measure required about $\$ 2.3$ trillion.

The Securities and Exchange Commission in its statement underlined the significance of robust disclosures and reporting during the pandemic.

A rule change was introduced to improve the effectiveness of the Small Business Administration.

The Federal Reserve Board temporarily modified rules concerning the PPP to enable certain banks and shareholders to apply for PPP loans for the needs of their small businesses.
The Main Street Lending Program was introduced to provide credits to SMEs with the purchase of up to $\$ 600$ billion in loans.

The scope and scale of the Primary and Secondary Market Corporate Credit Facilities, as well as the Term Asset-Backed Securities Loan Facility, were extended.

The Municipal Liquidity Facility was established, providing up to $\$ 500$ billion of loans to municipalities and states.

Table 2. The USA's Response to the Development of the COVID-19 Epidemic in 2020

Source: (The world bank group, 2020).

The US reaction to the development of the COVID-19 epidemic can also be divided into 2 parts: the first is support for financial institutions and regulation of their activities, the second is support for liquidity and pumping money into the economy. In addition, the US is actively subsidizing businesses and the public during the pandemic. 
Ilmir Nusratullin, Nikolay Mrochkovskiy, Raul Yarullin, Natalia Zamyatina y Oksana Solntseva The Financial Implications of the Coronavirus COVID-19 Pandemic: A Review

\begin{tabular}{|c|c|c|c|}
\hline Financial Institutions & $\begin{array}{l}\text { Financial } \\
\text { Markets }\end{array}$ & $\begin{array}{l}\text { Liquidity/ } \\
\text { funding }\end{array}$ & $\begin{array}{l}\text { Payment } \\
\text { systems }\end{array}$ \\
\hline 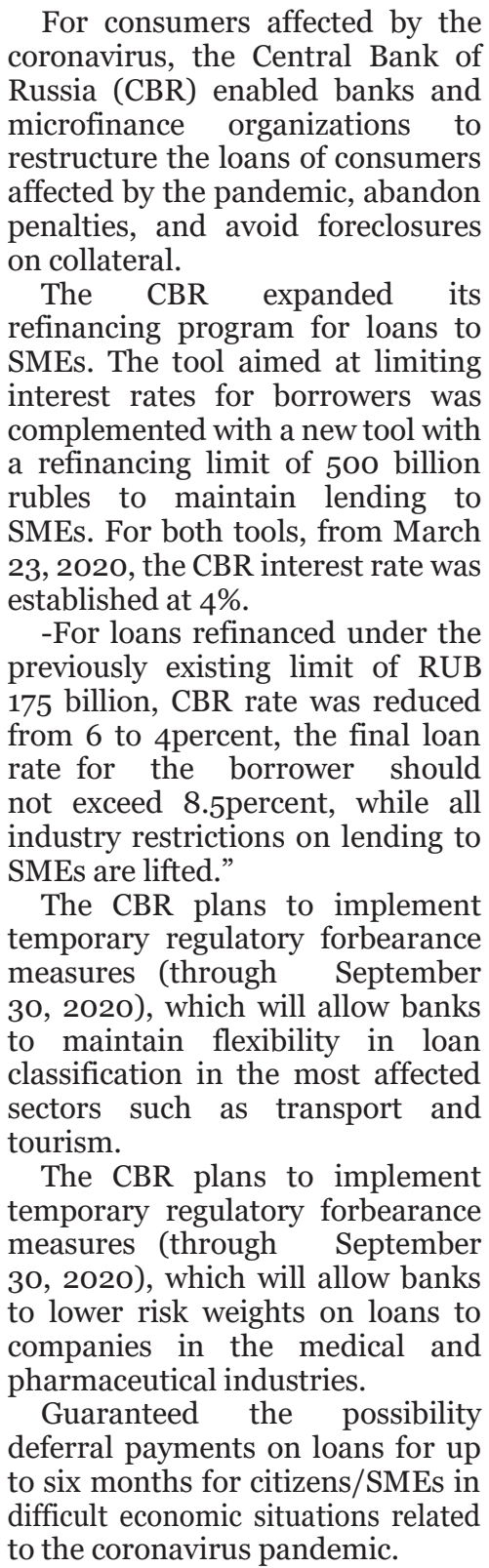 & $\begin{array}{l}\quad \text { The CBR } \\
\text { started } \\
\text { selling } \\
\text { FX on the } \\
\text { market for } \\
\text { the first } \\
\text { time in } \\
\text { five years } \\
\text { to lower } \\
\text { market } \\
\text { volatility } \\
\text { and } \\
\text { suspended } \\
\text { daily } \\
\text { purchases of } \\
\text { FX for state } \\
\text { reserves } \\
\text { for } 30 \text { days } \\
\text { to relieve } \\
\text { downside } \\
\text { pressure on } \\
\text { the ruble. }\end{array}$ & $\begin{array}{l}\text { Policy rates } \\
\text { were reduced by } \\
25 \text { basis points } \\
\text { to } 6 \% \text { on o2-07- } \\
2020 \\
\text { On March } \\
\text { 19th CBR } \\
\text { announced } \\
\text { daily sales } \\
\text { of FX on the } \\
\text { open market, } \\
\text { related to the } \\
\text { sale of CBR's } \\
\text { 5opercent } \\
\text { equity stake in } \\
\text { Sberbank to } \\
\text { the National } \\
\text { Wealth Fund. } \\
\text { Initially, this } \\
\text { deal was } \\
\text { supposed to } \\
\text { result in sale } \\
\text { of approx. } \\
\text { USD45 bln on } \\
\text { the local FX } \\
\text { market evenly } \\
\text { spread over } 3-7 \\
\text { years, however, } \\
\text { the sharp } \\
\text { deterioration } \\
\text { of the global } \\
\text { market } \\
\text { conditions } \\
\text { have lowered } \\
\text { the value of the } \\
\text { equity stake } \\
\text { in question to } \\
\text { approx. USD25 } \\
\text { ban and led to } \\
\text { aprompt } \\
\text { action. }\end{array}$ & $\begin{array}{l}\quad \text { In order } \\
\text { to simplify } \\
\text { online } \\
\text { money } \\
\text { transfers } \\
\text { between } \\
\text { individuals, } \\
\text { CBR sets the } \\
\text { limit value of } \\
\text { commissions } \\
\text { charged by } \\
\text { banks from } \\
\text { its customers } \\
\text { for transfers } \\
\text { between } \\
\text { individuals } \\
\text { from May } 1 \text {, } \\
\text { 2020. }\end{array}$ \\
\hline
\end{tabular}




The CBR introduced some
additional measures, which
included allowing credit
institutions to use assessments
made as of January 1, 2020 for
balance sheet assets and loan
loss provisioning; this measure
concerned loans classified under
Quality Categories I and II.
Credit institutions received
the opportunity to apply for risk
premiums when restructuring loan
debt from March 1 to September
30, 2020, as well as apply previous
(lower) premiums when calculating
risk ratios.
The Bank also announced that
it would implement Basel III
standards early for retail lending.
The scope of support programs
for SMEs was extended. In
particular, (1) the calculation of
debt limits was revised, and (2) the
in-person requirement for SMEs to
obtain loans related to supporting/
maintaining employment was
relaxed. The latter change was in
effect from April 6 through July 1,
202O.
Measures were taken to simplify
loan restructuring. Banks were
allowed to assess
their financial condition, the
quality category of loans, and the
quality of debt servicing as of March
1, 2020. This measure concerned
all activities not specified in the
previous CBR decisions. The CBR
also announced its intent to reduce
deposit insurance premiums from
o.15\% to o.1\% by the end of the
year.

Table 3. Russia's Response to the Development of the COVID-19 Epidemic in 2020

Source: (The world bank group, 2020). 
Before the COVID-19 pandemic, the Russian economy and financial system were already under serious pressure (economic crisis and sanctions, see Nusratullin et al, 2020a; Nusratullin et al, 2020b). But Russia has responded quite successfully to the COVID-19. Russia's reaction to the development of the COVID-19 epidemic can be divided into 4 parts:

1. Support of financial institutions and regulation of their activities (stimulating the restructuring of debts for small and medium-sized businesses, introducing the possibility of tax holidays).

2. Regulation of the foreign exchange market seeking to ease the pressure on the national currency (Ruble).

3. Supporting liquidity by pumping money into the economy.

4. Stimulation for electronic transfers, reducing cash operations.

Since not enough time has passed, the effectiveness of these measures is difficult to assess. All these measures are more about regulation of the financial sector during periods of serious global economic crises. This is understandable, since humanity at the present stage of development, this is the first time that modern society has met a global pandemic face to face.

\section{Conclusion}

The COVID-19 pandemic has shown that it can harm the global economy on an unprecedented scale. Unlike natural disasters, terrorist attacks, technological disasters and other factors of economic destabilization, the epidemic is global. The damage that COVID-19 brought and will bring remains to be calculated. The economy can be restored, but human lives are gone. The world scientific community is faced with the task of studying in detail the impact of global pandemics on humanity, including in the financial sphere, in order to develop an effective mechanism to confront it and its consequences.

\section{Bibliographic References}

AL JAZEERA 2020. Coronavirus: Travel restrictions, border shutdowns by country. Coronavirus pandemic News. Available online. In: https:// www.aljazeera.com/news/2020/03/coronavirus-travel-restrictionsborder-shutdowns-country-200318091505922.html. Consultation date: 02/02/2020.

AL-AWADHIA, Abdullah M.; ALSAIFIA, Khaled; AL-AWADHIB, Ahmad; ALHAMMADIC, Salah. 2020. "Death and contagious infectious diseases: Impact of the COVID-19 virus on stock market returns" In: Journal of Behavioral and Experimental Finance. Vol. 27.100326, 
ALlOCATI, Nerino; PETRUCCI, Anna Grazia; DI GIOVANNI, Pamela; MASULLI, Michelle; DI ILIO, Carmine; DE LAURENZI, Vincenzo. 2016. "Batman disease transmission: zoonotic pathogens from wildlife reservoirs to human populations" In: Cell death discovery. No. 2, pp. 16048.

ALSAIFI, Khaled; ELNAHASS, Marwa; SALAMA, Aly. 2020. "Market responses to firms' voluntary carbon disclosure: Empirical evidence from the United Kingdom” In: Journal of Cleaner Production. Vol. 262. 121377.

ARBELÁEZ-CAMPILLO, Diego; VILLASMIL ESPINOZA, Jorge. J. 2020. "Escenarios prospectivos de un nuevo orden internacional que se vislumbra luego de la pandemia COVID-19” In: Revista Telos. No. 22 (3), pp. 494 .

BACKER, Jantien A; KLINKENBERG, Don; WALLINGA, Jacco. 2020. "Incubation period of 2019 novel coronavirus (2019-nCoV) infections among travellers from Wuhan, China, 20-28 January 2020" In: Euro Surveill. Vol. 25, No. 5 .

BASH, Ahmad; ALSAIFI, Khaled. 2019. "Fear from uncertainty: An event study of Khashoggi and stock market returns" In: Journal of Behavioral and Experimental Finance. Vol. 23, pp. 54-58.

BLOOM, Davis E; CANNING, David. 2004. "Epidemics and economics: Interactions between global change and human health" In: Scripta Varia. No. 106, pp. 304-331. Available online. In: http://www.pas.va/ content/dam/accademia/pdf/sv106/sv106-bloom.pdf. Consultation date: $02 / 02 / 2020$.

BLOOM, David E; CADARETTE, Daniel; SEVILLA, J.P. 2018. "Epidemics and economics: New and resurgent infectious diseases can have far-reaching economic repercussions" In: Finance and Development. Vol. 55, No. 2, pp. 46-49. Available online. In: https://www.imf.org/external/pubs/ft/ fandd/2018/o6/economic-risks-and-impacts-of-epidemics/bloom.pdf. Consultation date: $02 / 02 / 2020$.

BONGINI, Paola; CUCINELLI, Doriana; DI BATTISTA, Maria Luisa; NIERI, Laura. 2019. "Profitability shocks and recovery in time of crisis evidence from European banks” In: Finance Research Letters. Vol. 30, pp. 233239.

BUCK, Tobias; ARNOLD, Martin; CHAZAN, Guy; COOKSON, Clive. 2020. Coronavirus declared a pandemic as fears of economic crisis mount. The Financial Times. Available online. In: https://www.ft.com/ content/d72f1e54-6396-11ea-b3f3-fe4680ea68b5. Consultation date: 05/03/2020. 
CAMPBELL, Andrew M. 2020. "An increasing risk of family violence during the Covid-19 pandemic: Strengthening community collaborations to save lives” In: Forensic Science International: Reports. Vol. 2. 100089.

CHAKRABORTYA, Indranil; MAITYB, Prasenjit. 2020. "COVID-19 outbreak: Migration, effects on society, global environment and prevention" In: Science of The Total Environment. Vol. 728. 138882.

CHEN, Ming-Hsiang; JANG, Soo Cheong (Shawn); KIM, Woo Gon. 2007. "The impact of the SARS outbreak on Taiwanese hotel stock performance: an event-study approach" In: International Journal of Hospitality Management. Vol. 26, No. 1, pp. 200-212.

GOOGLE NEWS. Coronavirus outbreak map COVID-19. 2020. Available online. In: https://news.google.com/covid19/map. Consultation date: 02/02/2020.

THE WORLD BANK GROUP. 2020. COVID-19 Finance Sector Related Policy Responses 2020. Available online. In: https://datacatalog.worldbank. org/dataset/covid-19-finance-sector-related-policy-responses. Consultation date: $02 / 02 / 2020$.

FAN, Yi; ZHAO, Kai; SHI, Zheng-Li; ZHOU, Peng. 2019. "Bat Coronaviruses in China" In: Viruses. Vol. 11, No. 3, pp. 210.

GOV.UK 2020. Guidance on social distancing for everyone in the UK. UK Government website. Available online. In: https://www.gov.uk/ government/publications/covid-19-guidance-on-social-distancing-andfor-vulnerable-people/guidance-on-social-distancing-for-everyonein-the-uk-and-protecting-older-people-and-vulnerable-adults. Consultation date: 05/03/2020.

GUO, Mengmeng; KUAI, Yicheng; LIU, Xiaoyan. 2020. "Stock market response to environmental policies: Evidence from heavily polluting firms in China” In: Economic Modelling. Vol. 86, pp. 306-316.

HUANG, Chaolin; WANG, Yeming; LI, Xingwang; REN, Lili; ZHAO, Jianping; HU, Yi. 2020. "Clinical features of patientsinfected with 2019 novel coronavirus in Wuhan, China” In: Lancet. Vol. 395, No. 10223, pp. 497506.

ICHEV, Riste; MARINČ, Matej. 2018. "Stock prices and geographic proximity of information: Evidence from the Ebola outbreak" In: International Review of Financial Analysis. Vol. 56, pp. 153-166.

KOWALEWSKI, Oskar; ŚPIEWANOWSKI, Piotr. 2020. "Stock market response to potash mine disasters" In: Journal of Commodity Markets. Vol. 20. 100124. 
LAGOARDE-SEGOT, Thomas; LEONI, Patrick L. 2013. "Pandemics of the poor and banking stability" In: Journal of Banking and Finance. Vol. 37, No. 11, pp. 4574-4583,

LEONI, Patrick L. 2013. "HIV/AIDS and banking stability in developing countries" In: Bulletin of Economic Research. Vol. 65, No. 3, pp. 225237.

LEWIS, Maureen. 2001. "The Economics of Epidemics" In: Georgetown Journal of International Affairs. Vol. 2, No. 2, pp. 25-31. Available online. In: www.jstor.org/stable/43134024. Consultation date: 02/02/2020.

NICOLA, Maria; ALSAFI, Zaid; SOHRABI, Catrin; KERWAN, Ahmed; ALJABIR, Ahmed; IOSIFIDIS, Christos; AGHA, Maliha; AGHA, Riaz. 2020. "The Socio-Economic Implications of the Coronavirus and COVID-19 Pandemic: a Review" In: International Journal of Surgery. Vol. 78, pp. 185-193.

NUSRATULLIN, Ilmir; KUZNETSOVA, Svetlana; GAZIZYANOVA, Yuliya; KUTSENKO, Ekaterina; BEREZHNAYA, Lubov. 2020a. "Socioeconomic development of Russia in terms of the BRICS countries' development” In: Amazonia Investiga. Vol. 9, No. 27, pp. 52-61.

NUSRATULLIN, Ilmir; SERGEEV, Nikolai; KUZNETSOV, Maxim; SHEINA, Anastasia; SHUBTSOVA, Lyudmila. 2020b. "Industrial development under sanctions pressure: evidence from Russia" In: Amazonia Investiga. Vol. 9, No. 28, pp. 465-474.

SHANAEV, Savva; GHIMIRE, Binam. 2019. "Is all politics local? Regional political risk in Russia and the panel of stock returns. In: Journal of Behavioral and Experimental Finance" Vol 21, pp. 70-82.

SOHRABI, Catrin; ALSAFI, Zaid; O'NEILL, Niamh; KHAN, Mehdi; KERWAN, Ahmed; AL-JABIR, Ahmed; IOSIFIDIS, Christos; AGHA, Riaz. 2020. "World Health Organization Declares global emergency: A review of the 2019 novel coronavirus (COVID-19)" In: International Journal of Surgery. Vol. 76, pp. 71-76.

TAM, Clarence C; KHAN, Mishal S; LEGIDO-QUIGLEY, Helena. 2016. "Where economics and epidemics collide: migrant workers and emerging infections" In: Lancet. Vol. 388, No. 10052, pp. 1374-1376.

TAMURA, S; SAWADA, Y. 2009. Consumption Insurance against Unforeseen Epidemics: The Case of Avian Influenza in Vietnam. In: RIETI Discussion Paper Series, 09-E-023. Available online. In: https://www.rieti.go.jp/jp/ publications/dp/ogeo23.pdf. Consultation date: 02/02/2020. 
Ilmir Nusratullin, Nikolay Mrochkovskiy, Raul Yarullin, Natalia Zamyatina y Oksana Solntseva

YACH, Derek; STUCKLER, David; BROWNELL, Kelly D. 2006. "Epidemiologic and economic consequences of the global epidemics of obesity and diabetes" In: Nature Medicine. Vol. 12, No. 1, pp. 62-66.

YANG, Yongshi; PENG, Fujun; WANG, Runsheng; GUAN, Kai; JIANG, Taijiao; XU, Guogang; SUN, Jinlyu; CHANG, Christopher. 2020. "The deadly coronaviruses: The 2003 SARS pandemic and the 2020 novel coronavirus epidemic in China” In: Journal of Autoimmunity. Vol. 109. 102434 . 


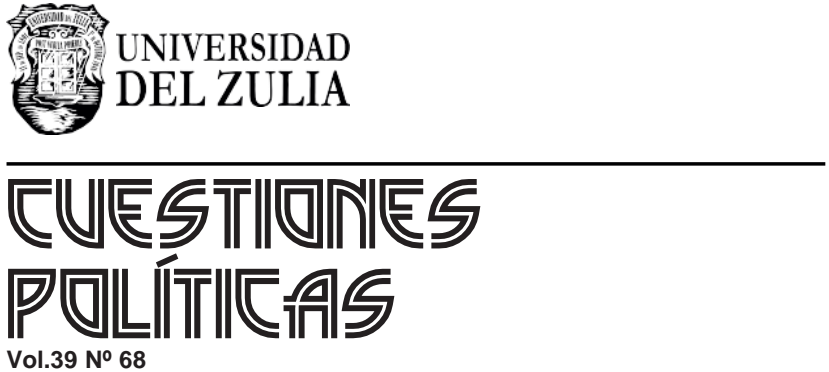

Esta revista fue editada en formato digital y publicada en enero de 2021, por el Fondo Editorial Serbiluz, Universidad del Zulia. Maracaibo-Venezuela 